\title{
Who Should Control the Integrated Management System for Sewerage Facilities in the Upper Reaches of Multi-Purpose Dams in Korea?
}

\author{
Kyoohong Park ${ }^{\dagger}$, Hyungjoon Kim \\ Department of Civil Engineering, Chung-Ang University, Seoul 156-756, Korea
}

\begin{abstract}
Integrated management systems (IMS) that control entire sewerage facilities in the upper reaches of multi-purpose dams are being constructed for their efficient operation and management. However, because the IMS installed in a watershed belong to several local government bodies, significant conflict would be expected between stakeholders in the process of deciding who should control the IMS after completion of the construction that was initially implemented under the support of central government. The objective of this study was to suggest a decision making to determine who should control the IMS for sewerage facilities in the upper reaches of multipurpose dams in Korea, using the analytic hierarchy process (AHP). Three alternatives were selected to determine who should control the IMS for sewerage facilities: commissioning to public corporations, commissioning to private corporations, and a role-sharing partnership. In using the AHP technique, the emphasis was on comparing public interests, economics, efficiency, sustainability, specialty, grievance mediation and receptiveness. As a result, building a role-sharing partnership received the highest score. Commissioning to a special institute was also suggested as an alternative as this showed a score similar to that of building a role-sharing partnership.
\end{abstract}

Keywords: Sewerage, Integrated management system, Analytic hierarchy process

\section{Introduction}

In 2004, while the sewage treatment rate in urban areas of Korea was $86.5 \%$, that in rural areas was $31.9 \%$. In particular, $32 \%$ of the upper reaches of multi-purpose dams were used as water supply sources in 2004. Therefore, the expansion of small-sized sewage treatment plants (STPs) has become an urgent issue for the preservation of the quality of water supply sources in the upper reaches of the dams. Thus, the government has planned to continue the installation of STPs for small sewage sources in the upper reaches of dams to enhance sewerage treatment rates up to $90 \%$ by 2015 [1].

According to the investment plan, 463 STPs and thousands of small-sized village sewerage plants will have been installed by 2011. The Korean Ministry of the Environment (KMOE) also developed the concept of an integrated sewerage management system (IMS) to control all of the sewerage facilities for their efficient operation and management, due to the difficulty encounter by only a few officials having to operate and maintain a number of STPs in a sparsely populated wide area. The outline of the IMS included the design of a central STP to operate and manage other STPs, such as village sewerage, in the basin using a remote automatic operating and monitoring system. The system was developed to save management costs and improve the efficiency of sewerage projects. It was also expected that the system would encourage not only higher efficiency of sewerage projects, but also the development of relevant technologies, such as information technology (IT) and environment technology (ET).

Although it was originally planned that this project would be implemented as a public-private partnership (such as BuildTransfer-Operate) program, as a result of the feasibility study [2, $3]$, it was decided to implement the program as a complete government-supported program with respect to the construction. With respect to the management, operation and maintenance of STPs, it was concluded to use the IMS in the STPs constructed throughout the wide basin area overseen by many local governments, as well as central government (KMOE), environmental management corporation (EMC; public corporation to commit sewerage construction management in Korea), and the related local governments.

Since the IMS installed in a watershed belongs to several local government bodies, significant conflict would be expected between local governments, inhabitants, non-governmental organizations (NGOs) and other related agencies as to who will be in charge of the IMS after completion of the construction that was implemented under the support of central government.

Received December 20, 2009 Accepted February 01, 2010

${ }^{\dagger}$ Corresponding Author

E-mail: kpark@cau.ac.kr

Tel: +82-2-820-5886 Fax: +82-2-812-4284 (c) This is an Open Access article distributed under the terms of the Creative Commons Attribution Non-Commercial License (http://creativecommons. org/licenses/by-nc/3.0/) which permits unrestricted non-commercial use, distribution, and reproduction in any medium, provided the original work is properly cited. 
Using the analytic hierarchy process (AHP), this study aimed to determine which entity should control the IMS for sewerage facilities in the upper reaches of multi-purpose dams in Korea.

\section{AHP Method Overview}

The AHP is a systematic analysis technique developed for multi-criteria decisions [4]. Its operating mode lays on the decomposition and structuring of a complex issue into several levels, rigorous definition of manager priorities and computation of weights associated with the alternatives. The output of the AHP is a ranking that indicates the overall preference for each decision alternative.

The AHP technique involves quantitative and qualitative feature in a unique analysis structure that converts the natural thoughts of any human being into an explicit process. The latter is implemented in a decision-support tool that provides objective and reliable results, even under different scenarios.

Assuming that $n$ decision factors are considered in the quantification process of the relative importance of each factor with respect to all the other factors, this problem can be set up as a hierarchy. Pairwise comparisons are then made between each pair of factors at a given level of the hierarchy, regarding their contribution toward the factor at the level immediately above. The comparisons are made on a scale of 1-9, as shown in Table 1 . This scale was chosen to support comparisons within a limited range, but with sufficient sensitivity. These pairwise comparisons yield a reciprocal $(n, n)$-matrix $A$, where $a_{i i}=1$ (diagonal elements) and $a_{i i}=1 / a_{i j}$

The method supposes that only the first column of matrix $A$ is required to state the relative importance of factors $2,3, \ldots$ . , $n$ with respect to factor 1 . If the judgments were completely consistent, then the remaining columns in the matrix would be completely determined due to the transitivity of the relative importance of the factors. However, there was no consistency, with the exception of that obtained by setting $a_{i i}=1 / a_{i j}$. Therefore, the comparison needed to be repeated for each column of the matrix, i.e. independent judgments had to be made over each pair. If after all the comparisons are made, matrix A should include

Table 1. Value scale for alternative decision comparisons [4]

\begin{tabular}{lll}
\hline $\begin{array}{l}\text { Comparison } \\
\text { intensity }\end{array}$ & Definition & Explanation \\
\hline 1 & $\begin{array}{l}\text { Equally } \\
\text { important }\end{array}$ & $\begin{array}{l}\text { Two decisions equally influence } \\
\text { the upper-level objective }\end{array}$ \\
3 & $\begin{array}{l}\text { Moderately more } \\
\text { important }\end{array}$ & $\begin{array}{l}\text { One decision is moderately more } \\
\text { favorable for the upper-level } \\
\text { objective fulfillment }\end{array}$ \\
5 & $\begin{array}{l}\text { Strongly more } \\
\text { important }\end{array}$ & $\begin{array}{l}\text { One decision is strongly more } \\
\text { favorable for the upper-level } \\
\text { objective fulfillment }\end{array}$ \\
7 & $\begin{array}{l}\text { Very strongly more } \\
\text { important }\end{array}$ & $\begin{array}{l}\text { One decision is significantly more } \\
\text { favorable for the upper-level } \\
\text { objective fulfillment }\end{array}$ \\
9 & $\begin{array}{l}\text { Extremely more } \\
\text { important }\end{array}$ & $\begin{array}{l}\text { The difference between influ- } \\
\text { ences of the two decisions is } \\
\text { extremely significant }\end{array}$ \\
& Intermediate & $\begin{array}{l}\text { When a compromise is necessary } \\
\text { to give an intermediary judgment } \\
\text { between the previous values }\end{array}$ \\
\hline
\end{tabular}

only exact relative weights.

Eq. (1) shows that multiplying the matrix by the vector of weights $w=\left(w_{1}, w_{2}, \ldots, w_{n}\right)$ yields

$$
A_{w}=\left[\begin{array}{cccc}
a_{1} & a_{1} & \cdots & a_{1 n} \\
a_{2} & a_{2} & \cdots & a_{2 n} \\
\cdots & \cdots & \cdots & \cdots \\
a_{n 1} & \cdots & \cdots & a_{n}
\end{array}\right]\left[\begin{array}{c}
w_{1} \\
w_{2} \\
\cdots \\
w_{n}
\end{array}\right]=\left[\begin{array}{cccc}
w_{1} / w_{1} & w_{1} / w_{2} & \cdots & w_{1} / w_{n} \\
w_{2} / w_{1} & w_{2} / w_{2} & \cdots & w_{2} / w_{n} \\
\cdots & \cdots & \cdots & \cdots \\
w_{n} / w_{1} & \cdots & \cdots & w_{n} / w_{n}
\end{array}\right]=n\left[\begin{array}{c}
w_{1} \\
w_{2} \\
\cdots \\
w_{n}
\end{array}\right]
$$

Therefore, to recover the overall scale from the matrix of ratios, the Eigenvector method was adopted [4]. According to the previous equation, the problem can be formulated as $A w=n w$ or $(A-n I)=0$, which represents a system of homogenous linear equations ( $I$ is the identity matrix). This system has a nontrivial solution if; and only if, the determinant of $(A-n I)$ vanishes, meaning that $\mathrm{n}$ has an Eigenvalue of $A$. Obviously, $A$ has a unit rank, since every row is a constant multiple of the first row and; thus, all Eigenvalues except one will be equal to zero. The sum of the Eigenvalues of a matrix equals its trace, and in this case, the trace of $A$ equals $\mathrm{n}$. Therefore, $\mathrm{n}$ has an Eigenvalue of $A$ and a nontrivial solution. The normalized vector is usually obtained by dividing all the entries, $w_{i}$ by their sum.

Thus, the scale can be recovered from the comparison matrix. In this exact case, the solution was any normalized column of $A$. Notably, matrix $A$ in this case was consistent, indicating that its entries satisfied the condition $a_{j k}=a_{i j} / a_{k i}$ (transitivity property).

However, in actual cases, precise values of $w_{i} / w_{j}$ are not available, but their estimates, which in general differ from the ratios of the actual weights, are provided by the decision-maker. The matrix theory illustrates that a small perturbation of the coefficients implies a small perturbation of the Eigenvalues. Therefore, an Eigenvalue close to $n$, which is the largest Eigenvalue, $\lambda_{\text {max }}$, should be found, since the trace of the matrix (equal to $n$ ) remains equal to the sum of the Eigenvalues, while small errors of judgment are made and other Eigenvalues are non-zero.

The solution to the problem of the largest Eigenvalue, which is the weight Eigenvector, w, corresponding to $\lambda_{\max }$ when normalized, gives a unique estimate of the underlying ratio scale between the elements in the studied case. Furthermore, the matrix whose entries are $w_{i} / w_{j}$ remains a consistent estimate of the "actual" matrix $A$, which may not be consistent. In fact, $A$ is consistent if; and only if, $\lambda_{\max }=n$. However, the inequality $\lambda_{\max }>n$ always exists. Therefore, the average of the remaining Eigenvalues can be used as a "consistency index" (CI), which is the difference between $\lambda_{\max }$ and $n$ divided by the normalizing factor $(n-1)$.

$$
C I=\frac{\lambda_{\max }-n}{n-1}
$$

The CI of the studied problem is compared with the average random index (RI) obtained from associated random matrices of order $n$ to measure the error due to inconsistency [4]. As a rule of thumb, a consistency ratio $(\mathrm{CR}=\mathrm{CI} / \mathrm{RI})$ value of $10 \%$ or less is considered acceptable, otherwise the pairwise comparisons should be revised.

\section{Hierarchical Scheme for AHP}

As shown in Fig. 1, a hierarchical scheme for the AHP [4] was designed to achieve successful utilization of the IMS for sewerage facilities in the upper reaches of multi-dams using an AHP. Three alternatives were selected to decide who should control 


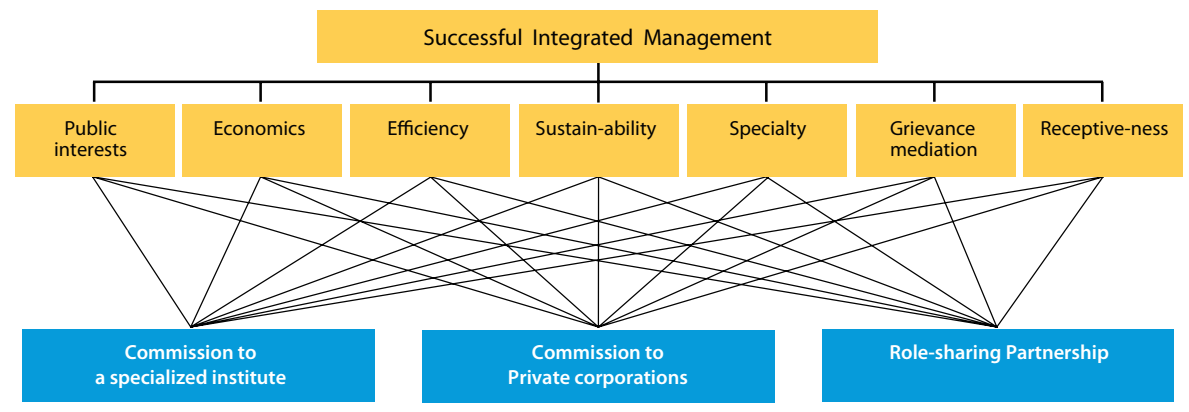

Fig. 1. Hierarchical scheme for the analytic hierarchy process.

the IMS for sewerage facilities:

Alternative 1: commission to a specialized institute, i.e. public corporations, such as the EMC. The association of related local governments still plays a role as a regulator. This alternative secures specialty, and derives independent and responsible management.
Alternative 2: commission to private corporations. This alternative promotes cost saving, application of advanced technology, and service quality control, etc.

Alternative 3: role-sharing partnership, which suggests that KMOE, local government, and a specialized institute, such as the EMC, share the role of managing, operating and maintain-

Table 2. Pros and Cons on the three alternatives for deciding who should control the IMS for sewerage facilities

\begin{tabular}{|c|c|c|}
\hline Alternative & Explanations & Pros \& Cons \\
\hline $\begin{array}{l}\text { 1. Commission to a } \\
\text { specialized institute }\end{array}$ & $\begin{array}{l}\text { The association of related local governments } \\
\text { commit to a specialized institute management, } \\
\text { operation, and maintenance of all STPs and } \\
\text { sewers including IMS. If necessary, a specialized } \\
\text { institute recommit to private corporations. }\end{array}$ & $\begin{array}{l}\text { Derives independent and responsible management, secures } \\
\text { specialty, and increases work efficiency. } \\
\text { Emphasizing independent management without responsible } \\
\text { management can result in lax management. In case public inter- } \\
\text { ests are not promoted, efficiency can be decreased. }\end{array}$ \\
\hline $\begin{array}{l}\text { 2. Commission to pri- } \\
\text { vate corporations }\end{array}$ & $\begin{array}{l}\text { The association of related local governments } \\
\text { commit to a private corporations management, } \\
\text { operation, and maintenance of all STPs and sew- } \\
\text { ers, including IMS. }\end{array}$ & $\begin{array}{l}\text { Participation of private corporation promotes resource supply, } \\
\text { scheduling, risk reduction, cost saving, application of advanced } \\
\text { technology, service quality control, etc. } \\
\text { Local governments lose competence to control STPs etc. Negativ- } \\
\text { ity due to long term contract and uncertainty related to legal and } \\
\text { administrative factors can be expected }\end{array}$ \\
\hline $\begin{array}{l}\text { 3. Role-sharing Part- } \\
\text { nership }\end{array}$ & $\begin{array}{l}\text { KMOE, local governments, and EMC or a special- } \\
\text { ized institute participate in the management, op- } \\
\text { eration, and maintenance of all STPs and sewers, } \\
\text { including IMS, by playing each pre-designated } \\
\text { role. }\end{array}$ & $\begin{array}{l}\text { Ensures public interests on water quality of the watershed by } \\
\text { playing a central government role as the regulator. } \\
\text { Minimizes the conflicts by admitting sovereignty of local govern- } \\
\text { ment } \\
\text { Secures specialty by a participating special institute. } \\
\text { Private corporation can still participate. } \\
\text { Must set local governments agreement on sharing costs as a } \\
\text { premise. }\end{array}$ \\
\hline
\end{tabular}

STPs: sewage treatment plants, IMS: integrated management system, KOME: Korean Ministry of the Environment, EMC: environmental management corporation.

Table 3. Description of each factor influencing the IMS for sewerage facilities

\begin{tabular}{ll}
\hline Public interests & $\begin{array}{l}\text { A sense of public duty and responsibility on sewerage management considering } \\
\text { the preservation of water supply sources, improvement of quality and watershed management efficiencies. } \\
\text { Economics }\end{array}$ \\
Pfficiency & $\begin{array}{l}\text { Efficability to save the cost of O\&M by IMS. } \\
\text { Continuing to utilize the newly devised standardized system related to the } \\
\text { existing and newly constructed sewerage facilities. } \\
\text { Involvement of specialized IT and ET technicians related to sewerage process } \\
\text { engineering, sewer O\&M techniques. }\end{array}$ \\
Specialty & $\begin{array}{l}\text { Ability for arbitration and intervention in conflicts and grievances between } \\
\text { central government, local governments, inhabitants, and NGOs. }\end{array}$ \\
Grievance mediation & Acceptability of newly established organization and amicableness to support operational fee \\
Receptiveness &
\end{tabular}


Table 4. Comparison matrix for each factor (an illustration answered by a respondent)

\begin{tabular}{|c|c|c|c|c|c|c|c|}
\hline & $\begin{array}{l}\text { Public } \\
\text { interests }\end{array}$ & $\underset{\text { ics }}{\text { Econom- }}$ & - Efficiency & $\begin{array}{l}\text { Sustaina } \\
\text {-bility }\end{array}$ & Specialty & $\begin{array}{c}\text { y Grievance } \\
\text { media- } \\
\text { tion }\end{array}$ & $\begin{array}{l}\text { Receptive } \\
\text {-ness }\end{array}$ \\
\hline Public interests & 1.00 & 3.56 & 3.06 & 1.76 & 1.80 & 2.90 & 2.88 \\
\hline Economics & 0.28 & 1.00 & 0.61 & 0.86 & 0.33 & 0.54 & 0.63 \\
\hline Efficiency & 0.33 & 1.63 & 1.00 & 1.03 & 0.52 & 0.79 & 0.89 \\
\hline Sustainability & 0.57 & 1.16 & 0.97 & 1.00 & 0.66 & 1.10 & 1.21 \\
\hline Specialty & 0.55 & 2.99 & 1.92 & 1.51 & 1.00 & 1.99 & 2.46 \\
\hline Grievance mediation & 0.34 & 1.84 & 1.26 & 0.91 & 0.50 & 1.00 & 1.49 \\
\hline Receptiveness & 0.35 & 1.59 & 1.12 & 0.82 & 0.41 & 0.67 & 1.00 \\
\hline
\end{tabular}

Table 5. Weights and ranks of each factor for a successful integrated management of sewerage system

\begin{tabular}{lcc}
\hline & Weights (\%) & Ranking \\
\hline Public interests & 28.88 & 1 \\
Economics & 7.27 & 7 \\
Efficiency & 10.23 & 5 \\
Sustainability & 11.99 & 3 \\
Specialty & 20.12 & 2 \\
Grievance mediation & 11.78 & 4 \\
Receptiveness & 9.73 & 6 \\
Total & 100.00 & - \\
\hline
\end{tabular}

Table 6. Evaluated results for each factor and each alternative (\%)

\begin{tabular}{lccccccc}
\hline & $\begin{array}{c}\text { Public } \\
\text { interests }\end{array}$ & $\begin{array}{c}\text { Econom } \\
\text {-ics }\end{array}$ & Efficiency & $\begin{array}{c}\text { Sustaina } \\
\text {-bility }\end{array}$ & $\begin{array}{c}\text { Profession } \\
\text {-alism }\end{array}$ & $\begin{array}{c}\text { Grievance } \\
\text { mediation }\end{array}$ & $\begin{array}{c}\text { Receptive } \\
\text {-ness }\end{array}$ \\
\hline Alt. 1 & 40.02 & 29.84 & 40.04 & 42.11 & 40.48 & 23.42 & 23.74 \\
Alt. 2 & 15.86 & 55.05 & 35.04 & 21.32 & 33.58 & 13.84 & 14.67 \\
Alt. 3 & 44.12 & 15.11 & 24.92 & 36.58 & 25.94 & 62.73 & 61.59 \\
\hline
\end{tabular}

Alternative 1: means commission to public corporations. Alternative 2: means commission to private corporations. Alternative 3: means the role-sharing partnership.

Table 7. Final scores and ranks of the three alternatives

\begin{tabular}{ccc}
\hline & Conversion score & Ranking \\
\hline Alternative 1 & 91.64 & 2 \\
Alternative 2 & 62.32 & 3 \\
Alternative 3 & 100.00 & 1 \\
\hline
\end{tabular}

ing the IMS for sewerage facilities. Table 2 shows the pros and cons when each alternative is implemented.

The seven factors influencing the decision as to who should control the IMS, as well as achieving the goal of successful utilization of IMS, were selected via a brainstorming conference. Table 3 shows the descriptions of the seven factors.

\section{Data Analysis and Results}

A questionnaire, composed of pairwise comparisons, was prepared based on the predetermined hierarchical scheme and sent to experts (engineering consultants, operators of STPs, and university professors) engaged in the field of sewerage design and construction. In this study, 31 different individuals provided independent comparison values. The comparison framework, as outlined above, was carefully explained to each evaluator, who was then asked to quantify accordingly the comparison values for all factors and alternatives.

Tables 2 and 3 were used to provide a common basis for the comparisons, although each evaluator was free to make their own decision regarding the consequences. A typical comparison matrix is shown in Table 4.

After receiving 31 answers, the analysis was performed using MS-Excel, with the rates of inconsistency for each factor evaluated. The CI was calculated as 0.01 , whereby the ratio $\mathrm{CI} / \mathrm{RI}=$ $0.014 / 1.320=0.011<0.1$. In all cases, the evaluators stayed within this constraint; thus, the consistency level regarding the weights was satisfactory.

Table 5 shows the calculated weights and ranks of each factor. Public interest received the highest weight; whereas, receptiveness received the lowest weight for successful IMS of sewerage system.

The evaluated results for each factor and each alternative are shown in Table 6. Commissioning to a special institute (Alternative 1) received the highest score for sustainability, but the lowest for grievance mediation. Commissioning to a private corporation (Alternative 2) received the highest score for economics, but the lowest for grievance mediation. The role-sharing partnership (Alternative 3) received the highest score for grievance mediation, but the lowest for economics.

Table 7 shows the final scores and ranks for the three alternatives. As a final result, the role-sharing partnership (Alternative 3 ) received the highest score (conversed score of 100). Although commissioning to a special institute (Alternative 1) received the medium score, the difference in the scores between alternatives 1 and 3 was very slight. Thus, alternative 1 cannot be overlooked as a possibility without careful consideration. It was notice that the complete commissioning to a private corporation showed a significantly lower preference than the other alternatives.

\section{Conclusions}

In this study, an attempt was been made to compare different entity alternatives for the successful implementation of the management, operation and maintenance of the IMS for sewerage facilities in the upper reaches of multi-purpose dams in Korea. Three alternatives were considered in deciding who should control the IMS for sewerage facilities: commissioning to public corporations, commissioning to private corporations, or a rolesharing partnership. In using the AHP technique, the emphasis 
was on comparing public interests, economics, efficiency, sustainability, specialty, grievance mediation and receptiveness.

The role-sharing partnership (Alternative 3) received the highest score (conversed score of 100). Although commissioning to a special institute (Alternative 1) received the second highest score of the three alternatives, the difference in the scores between alternatives 1 and 3 was not significant. Thus, alternative 1 cannot be easily dismissed as a method without careful consideration. These results lead us to the conclusion that decisionmakers can choose either alternative 1 or 3 .

\section{Acknowledgments}

This research was supported by a Chung-Ang University Research Grants in 2005-2006.

\section{References}

1. Korean Ministry of Environment. Integrated management system for sewerage facilities and BTL project for sewage pipe in Korea. Korea Environ. Policy Bull. 2005;III (1).

2. Park K, Jin YS, Lee S. Feasibility study on sewerage rehabilitation project in upper reaches of dams Andong-Imha. Final report to Environmental Management Corporation, Korea; 2003 (in Korean).

3. Park K, Jeong DH, Jin YS, Kim J. Application of benefit transfer method in planning the construction of the integrated sewerage system at the catchment areas of dams in Korea. In: Proceedings of International Conference on Water Economics, Statistics, and Finance; 2005 Jul 8-10; Rethymno, Greece: International Water Association.

4. Saaty TL. Analytical hierarchy process: planning, priority setting, resource allocation. New York: McGraw-Hill; 1980. 
